\title{
Patient Characteristics, Financing Type, Accreditation Status, and Quality of Health Services at Community Health Center, Surakarta
}

\author{
Yeni Tri Utami'), Didik Tamtomo²), Endang Sutisna Sulaeman²) \\ 1)Masters Program in Public Health, Universitas Sebelas Maret \\ 2)Faculty of Medicine, Universitas Sebelas Maret
}

\begin{abstract}
Background: An indicator of quality health service is the extent of patient expectation fulfilment. Perceived quality of health services may be influenced by various factors such as patient sociodemographic factors, financing type, and accreditation status. As statistics have shown, the number of patient visits at Surakarta Community Health Center has been decresing for the last few years. This study aimed to determine the associations between patient characteristics, financing type, accreditation status, and the quality of health services at community health center.

Subjects and Method: This was a quantitative study with cross-sectional design. It was conducted at Community Health Center, Surakarta, Central Java, from May to July 2017. A sample of 120 patients were selected for this study from 2 Community Health Centers selected at random from all 17 Community Health Centers existing in Surakarta. The independent variables were patient characteristics, financing type, and accreditation status of the Community Health Centers selected. The dependent variable wasquality of health service. The data were collected using a set of questionnaire and analyzed using multiple logistic regression.

Results: Quality of health service was negatively associated with patient education $(\mathrm{OR}=0.27$; $95 \% \mathrm{CI}=0.08$ to $0.90 ; \mathrm{p}=0.033)$, being employed $(\mathrm{OR}=0.15 ; 95 \% \mathrm{CI}=0.04$ to $0.48 ; \mathrm{p}=0.002)$, higher patient income $(\mathrm{OR}=0.28 ; 95 \% \mathrm{CI}=0.08$ to $0.94 ; \mathrm{p}=0.039)$, being insured $(\mathrm{OR}=3.06 ; 95 \%$ $\mathrm{CI}=0.81$ to $11.52 ; \mathrm{p}=0.099)$, and higher accreditation status of Community Health Care (OR= $2.96 ; 95 \% \mathrm{CI}=1.03$ to $8.50 ; \mathrm{p}=0.044)$.

Conclusion: Quality of service at Community Health Care is negatively associated with patient education, being employed, higher patient income, being insured, and higheraccreditation status.
\end{abstract}

Keywords: patient characteristic, financing type, accreditation status, quality of services

\section{Correspondence:}

Yeni Tri Utami. Masters Program in Public Health, Universitas Sebelas Maret. Jl. Ir. Sutami 36 A, Surakarta 57126, Central Java. Email: yenie_03@yahoo.co.id. Mobile: +6285642339053.

\section{BACKGROUND}

$\overline{\text { Efforts to improve the quality of health ser- }}$ vices are the most important step to improve the competitiveness of health sectors in Indonesia. The quality improvement is not only for hospitals, but also applies to all levels of health services ranging from community health center or the first service facilities to advanced health care facilities, both in government and private facilities (Azwar, 2009). Improving the quality of health services is very important in order to realize optimal service for customers or patients.

Assessment of the quality of care by patients is influenced by several aspects, one of which is patient demographic factors. According to Ibraheem et al. (2013), demographic factors that are significantly related to quality assessment include gender, religion, age, occupation, education, and patient domicile. According to a study conducted by Jafari et al. (2014), patient demographics or patient domicile, 
Journal of Health Policy and Management (2017), 2(1): 81-92

https://doi.org/10.26911/thejhpm.2017.02.01.07

education, and patient income are factors that influence the assessment of service quality. Other factors that can influence the quality of health services are seen from the financing type to health care providers.

The association of differences in the financing membership status of with the assessment of the quality of patient care is known to have a significant association. Patients with contributions paid by the Government tend to feel satisfied with the existing system. Complaints and many dissatisfied statements arose from wage recipients and whose contributions were paid independently because several participatory procedures were deemed complicated and lack of socialization regarding the ongoing JKN (National Health Insurance) system. In addition, because they feel they have fulfilled their obligations by paying contributions every month, the expectations for better health services are higher (Christasani, 2016).

The implementation of health services in the JKN era includes all health facilities in collaboration with BPJS Kesehatan (Healthcare Social Security Agency) developed with the concept of tiered services. This tiered form of service is known as a referral system that establishes referral procedures as provisions that must be followed by all participants (Andini, 2014). The patient's referral system is still ineffective and inefficient, there are still many people unable to reach health services and patients consider the bureaucratic referral system to be quite complicated, so patients directly refer to themselves or choose to pay for themselves and do not use the insurance they have to get second-rate health facilities or third. Various factors that influence include physician competence, funding, and infrastructure that has not been supported (Ali, 2015).
Based on data from Health Development Efforts, Surakarta has basic health facilities as the first service facility for 17 community health centers. If calculated from the ratio of health service facilities to population, Surakarta is quite adequate. However, what needs to be improved is the quality of service to the community. The number of utilization of existing health facilities is obtained from the community health centers' report. Results that were obtained in 2014 stated that the number of new visits and the duration of the community health center were 725,636. The average visit per community health center / day was 142 patients. Looking at these data, compared to 2013 (the average visit per community health center/ day was 153 patients) there was a decrease in the number of visits to the community health center. Patient visits also decreased in 2015 as many as 653,223 patients with an average visit of each community health center/ day as many as 128 patients. In 2016, there was a decrease in the average visits of each community health center/ day as many as 123 patients from a total 628,788 patients. This needs to be analyzed further related to whether the decrease in patient visits to the community health center is decreasing due to the increasing degree of public health or because of a decrease in public interest in services at the community health center (Surakarta Health Profile, 2014, 2015, 2016).

The data above shows that the highest visit was at the Sangkrah Health Center and the lowest visit was at the Penumping Health Center. Based on a preliminary survey at the Surakarta Health Office, there were 11 accredited health centers, and 6 health centers that had not been accredited (including Penumping, Purwosari, Purwodiningratan, Gilingan, Banyuanyar and Gambirsari Health Center) out of 17 health 
centers. Based on these data, the author wanted to know the quality of health services in accredited health centers and health centers that has not been accredited to see whether there is an association between the quality of services provided to patients.

Satisfaction arises based on the fulfillment of patient expectations for the service it receives. The concept of the study of evaluating service quality is the five quality dimensions concept or service quality known as Service Quality (SERVQUAL) developed by Kotler (2009), namely: (1) reliability; (2) responsiveness; (3) assurance; (4) empathy; and (5) direct evidence (tangibles).

Based on the description above, the writer was interested in conducting a study entitled "Patient Characteristics, Financing Type, Accreditation Status, and Quality of Health Services at Community Health Center, Surakarta".

\footnotetext{
SUBJECTS AND METHOD

1. Design of the study

The design of this study used a quantitative approach with a cross sectional approach. This study was conducted in Sangkrah and Penumping Health Center, Surakarta on May to July 2017.
}

\section{Population and Sample}

The population in this study was the number of outpatients in health center in Surakarta ( 17 health centers). The sample in this study used cluster random sampling. The number of samples was 120 subjects of the study, it were obtained from 2 health centers representing accredited health center and health center that has not been accredited

\section{Study Variables}

The independent variables of this study included patient characteristics, financing type, and accreditation status of health service providers, while the dependent variable was the health service quality.

\section{Operational Definition of Variables}

Education was the education stage that was determined based on the highest school graduation achieved by the subject of the study based on the ownership of the last certificate, with a categorical data scale consisting of <Senior High School and $\geq$ Senior High School, which were measured using a questionnaire.

Working status was the status of a person in doing a job with the intention of earning income, with a categorical data scale consisting of unemployed and employed and it was measured using a questionnaire.

Financing typewas the total amount of income obtained from a fixed or a side income within one month and realized in terms of money or rupiah, with a categorical data scale consisting of <regional minimum wage and $\geq$ regional minimum wage, measured using a questionnaire.

The financing type was the way health care users pay to health centers for receiving health services, with a categorical data scale consisting of general (Out of Pocket) and Healthcare Social Security Agency, which were measured using a questionnaire.

The status of accreditation of health service providers was the recognition of health centers provided by independent institutions that administer accreditation set by the Minister, with a categorical data scale consisting of had not been accredited and had already been accredited and measured by using a questionnaire.

Patient satisfaction was measured by SERVQUAL questionnaire

\section{Reliability Test}

Reliability test on service quality variables could be seen in table 1 . 
Journal of Health Policy and Management (2017), 2(1): 81-92

https://doi.org/10.26911/thejhpm.2017.02.01.07

\section{Data analysis}

Univariate data analysis of sample categorical data was described using the para- meters $\mathrm{n}$ and\%. Bivariate analysis used Chi Square. Multivariate analysis used multiple logistic regressions.

Tabel 1. The result of reliability test

\begin{tabular}{lcc}
\hline \multicolumn{1}{c}{ Variable } & Total Correlation Item (r) & Cronbach's Alpha \\
\hline Tangible & $\geq 0.25$ & $\geq 0.83$ \\
Reliability & $\geq 0.23$ & $\geq 0.84$ \\
Responsiveness & $\geq 0.51$ & $\geq 0.74$ \\
Assurance & $\geq 0.38$ & $\geq 0.88$ \\
Empathy & $\geq 0.48$ & $\geq 0.76$ \\
\hline
\end{tabular}

\section{RESULT}

Based on Table 2, it can be seen that of the female $(83.3 \%)$ with the highest age of $17-$ 55 years $(87.5 \%)$.

120 study subjects, the majority were

Table2.Characteristics of thestudy subjects

\begin{tabular}{llcc}
\hline \multicolumn{1}{c}{ Criteria } & \multicolumn{1}{c}{ Clasification } & n & \% \\
\hline Gender & Male & 20 & 16.7 \\
Age & Female & 100 & 83.3 \\
& 17-55years & 105 & 87.5 \\
Education & 56-65years & 15 & 12.5 \\
\multirow{2}{*}{ Working status } & < Senior High School & 40 & 33.3 \\
& 2Senior High School & 80 & 66.7 \\
& Unemployment & 52 & 43.3 \\
Income & Employment & 68 & 56.7 \\
& TOTAL & 120 & 100 \\
Financing type & <regional minimum wage & 72 & 60 \\
& 2regional minimum wage & 48 & 40 \\
\multirow{3}{*}{ Accreditation Status } & 32 & 26.7 \\
\multirow{2}{*}{ Service quality } & General & 88 & 73.3 \\
& Healthcare Social Security & & \\
& Agency & 60 & 50 \\
& Not yet accredited & 60 & 50 \\
& Acredited & 59 & 49.2 \\
\hline
\end{tabular}

Based on table 2, it can be seen that out of 120 subjects of the study, $66.7 \%$ of the subjects of the study had an education level $\geq$ Senior High School, 56.7\% with working status, and $60 \%$ had <regional minimum wage income. The financing type used by subjects of the study was mostly from Healthcare Social Security Agency, which was $73.3 \%$ both PBI (Premium Assistance Recipients) and non-PBI.

The subjects of the study taken were $50 \%$ from the community health centers that had not been accredited and $50 \%$ of the community health centersthat had been accredited. Based on the results of mea- surements of the quality of health services, 49.2\% stated that the quality of outpatient services in Sangkrah and Penumping Community Health Center was poor and the remaining $50.8 \%$ stated that they were good.

Table 3 shows that the education of the subjects of the study<senior high school influenced the assessment of the quality of outpatient services by $17.5 \%$ and $82.5 \%$ gave good assessment. While the junior high school study subjects influenced the assessment of the quality of outpatient services by $65 \%$ and $35 \%$ giving good assessmets, with a value of $\mathrm{p}<0.001$. 
The status of study subjects who did not work influenced the assessment of the quality of outpatient services. $13.5 \%$ study subject gave poor assessmenta and $86.5 \%$ gave good assessment. The study subjects who worked influenced the assessment of the quality of outpatient services. $76.5 \%$ study subject gave poor assessments and $23.5 \%$ gave good assessments, with a value of $\mathrm{p}<0.001$.

Table3. The correlation bivariate test between patient education, work status, income, financing type, and accreditation status and the quality of health service

\begin{tabular}{|c|c|c|c|c|c|c|}
\hline \multirow{3}{*}{ Variable } & \multirow{3}{*}{ Category } & \multicolumn{4}{|c|}{ Service Quality } & \multirow{3}{*}{$\mathbf{p}$} \\
\hline & & \multicolumn{2}{|c|}{ Poor } & \multicolumn{2}{|c|}{ Good } & \\
\hline & & $\mathbf{n}$ & $\%$ & $\mathbf{n}$ & $\%$ & \\
\hline \multirow{2}{*}{ Patients' education } & $<$ Senior High School & 7 & 17.5 & 33 & 82.5 & \multirow{2}{*}{$<0.001$} \\
\hline & $\geq$ Senior High School & 52 & 65 & 28 & 35 & \\
\hline \multirow{2}{*}{ Working status } & Unemployed & 7 & 13.5 & 45 & 86.5 & \multirow{2}{*}{$<0.001$} \\
\hline & Employed & 52 & 76.5 & 16 & 23.5 & \\
\hline \multirow{2}{*}{ Income } & $\begin{array}{l}<\text { regional minimum } \\
\text { wage }\end{array}$ & 18 & 25 & 54 & 75 & \multirow{2}{*}{$<0.001$} \\
\hline & $\begin{array}{l}\geq \text { regional minimum } \\
\text { wage }\end{array}$ & 41 & 85.4 & 7 & 14.6 & \\
\hline \multirow[t]{2}{*}{ Financing type } & $\begin{array}{l}\text { General } \\
\text { Healthcare Social }\end{array}$ & 25 & 78.1 & 7 & 21.9 & \multirow[t]{2}{*}{$<0.001$} \\
\hline & Security Agency & 34 & 38.6 & 54 & 61.4 & \\
\hline \multirow{2}{*}{ Accreditation Status } & $\begin{array}{l}\text { Had not been } \\
\text { accredited }\end{array}$ & 37 & 61.7 & 23 & 38.3 & \multirow{2}{*}{0.006} \\
\hline & $\begin{array}{l}\text { Had already been } \\
\text { accredited }\end{array}$ & 22 & 36.7 & 38 & 63.3 & \\
\hline
\end{tabular}

Study subject income <regional minimum wage influenced the assessment of the quality of outpatient services. $25 \%$ study subjects gave poor assessment and $75 \%$ gave good assessments. While the income of the minimum wage of study subject influenced quality of outpatient services. $85.4 \%$ gave poor assessments and $14.6 \%$ gavegood assessments, with a value of $\mathrm{p}<0.001$.

The financing type for study subjects through general way or by using personal expensesinfluenced the assessment of the quality of outpatient services. $78.1 \%$ gave poor assessments and 21.9\% gave good assessments. While the financing typefor study subjects by BPJS (PBI and non-PBI) influenced the assessment of the quality of outpatient services. $38.6 \%$ gave poor assessments and $61.4 \%$ gave good assessments, with a value of $\mathrm{p}<0.001$.
The accreditation status of health centers with unaccredited influenced the assessment of study subjects on the quality of outpatient services. $61.7 \%$ study subjects gave poorassessment and $38.8 \%$ gave good assessment. Whereas the place of the health service provider with accredited status influenced the assessment of the quality of outpatient services. $36.7 \%$ gave poor assessments and $63.3 \%$ gave good assessments, with a value of $\mathrm{p}=0.006$

Based on Table 4, the results of the multiple logistic regression equation can be explained as follows:

There was an influence between patient education and service quality assessment and was statistically significant $(\mathrm{p}=$ 0.033). Patients with $\geq$ senior high school education level wereo.27 (1/4) times less likely to give good assessments of the quality of outpatient services. Whereas patients with $<$ senior high school education 
Journal of Health Policy and Management (2017), 2(1): 81-92

https://doi.org/10.26911/thejhpm.2017.02.01.07

were $0.27(1 / 4)$ times less likely to give

poorassessmentsthan patients who had an

education $\geq$ senior high school $(\mathrm{OR}=0.27$;

$95 \% \mathrm{CI}=0.08$ to $0.90 ; \mathrm{p}=0.033)$.

Table 4. The results of multiple logistic regression characteristics of the study subjects, financing type, and accreditation status on the quality of outpatient services

\begin{tabular}{lcccc}
\hline \multirow{2}{*}{ Independent Variables } & \multirow{2}{*}{ OR } & \multicolumn{2}{c}{$\mathbf{9 5 \%}$ CI } & \multirow{2}{*}{ p } \\
\cline { 3 - 4 } & & Lower limit & Upper limit & 0.90 \\
Patients Education & 0.27 & 0.08 & 0.033 \\
Working status & 0.15 & 0.04 & 0.48 & 0.002 \\
Patient Income & 0.28 & 0.08 & 0.94 & 0.039 \\
Financing type & 3.06 & 0.81 & 11.52 & 0.099 \\
Accreditation status & 2.96 & 1.03 & 8.50 & 0.044 \\
N Observation = 120 & & & & \\
-2 Log Likelihood & 93.5 & & & \\
Nagelkerke R Square & $60.6 \%$ & & & \\
\hline
\end{tabular}

There was an influence between the working status of patients on the assessment of service quality and it was statistically significant $(\mathrm{p}=0.002)$. Patients with working status were 0.15 times less likely to give good assessments of the quality of outpatient services. Whereas patients with non-working status were 0.15 times less likely to give poor assessments than patients who had working status $(\mathrm{OR}=0.15$; 95\% CI $=0.04$ to $0.48 ; \mathrm{p}=0.002$ ).

There was an influence between patients income on the assessment of service quality and was statistically significant $(\mathrm{p}=$ o.039). Patients within come $\geq$ regional minimum wage were 0.28 times less likely to give good assessments of the quality of outpatient. Patients with income $<$ regional minimum wage were $0.28(1 / 4)$ times less likely to give poor assessments than patients with income $\geq$ regional minimum wage $(\mathrm{OR}=0.28 ; 95 \% \mathrm{CI}=0.08$ to $0.94 ; \mathrm{p}$ $=0.039$ ).

There was an influence between the financing type and the assessment of service quality and was statistically close to significant $(\mathrm{p}=0.099)$. Patients who used BPJS (BPI and non-PBI) were 3.06 times more likely to give good assessments of the quality of outpatient services. While patients with the out-of-pocket cost, it was
3.06 times more likelyto give poor assessment than patients who used the out-ofpocket cost $(\mathrm{OR}=3.06 ; 95 \% \mathrm{CI}=0.81$ to 11.52; $\mathrm{p}=0.099)$.

There was an influence between community health center accreditation status on service quality and it was statistically significant $(\mathrm{p}=0.044)$. Community health centers with accredited status were 2.96 times more likely to be given good assessments of the quality of outpatient. Whereas community health centers with an unaccredited status were 2.96 times more likely to be given poor assessments (OR $=2.96$; $95 \%$ $\mathrm{CI}=1.03$ to $8.50 ; \mathrm{p}=0.044)$.

The value of Negelkerke $\mathrm{R}^{2}$ was $60.6 \%$, this meant that the five independent variables (patient education, work status, patient income, financing type, and accreditation status of community health center) were able to explain the factors that influenced the assessment of service quality by $60.6 \%$ and the remaining $39.4 \%$ was explained by other factors outsidethe study.

\section{DISCUSSION \\ 1. The Influence of patient charac- teristics on the quality of health services}

The results of statistical data analysis showed that there is an influence of patient 
characteristics which consisted of patient education, work status and patient income on the assessment of the quality of health services, and is statistically significant. Decision-making in purchasing processes weredirectly influenced by individual characteristics (patients), psychological factors, and indirectly by social and cultural factors. So, consumer behavior is an aggregation of factors that influence consumer behavior in buying and post purchasing (Kusumapradja, 2013).

Patient education shows that there is an influence on the assessment of the quality of outpatient services; the influence is negative and statistically significant. The results showed that patients who went to community health centers were mostly with education $\geq$ senior high school (senior high school, vacatioinal high school, business and management vocational high school, third level of associate's degree and bachelor). Patients with senior high school education tend to give poor assessments than good assessments of the quality of outpatient services. This is in accordance with the study of Afzal et al. (2014), Naseer et al., (2012), which stated that the level of education is significantly related to the level of assessment of service quality seen from patient satisfaction. Please note that educated patients will be less satisfied than highly educated people. The average of satisfaction level is relatively less in patients who have bechelor or master degree. Higher levels of education are associated with lower patient satisfaction levels. Educated patients tend to have a good understanding of the disease and they expect better communication from health care providers.

This is also in line with the results of study conducted by Ammo et al., (2014) and Shah and Baba (2016), which showed that patients with elementary education levels were significantly more satisfied than patients with post-graduate education. The results of a study in a hospital found that low-educated patients tended to rate hospital services more positively than those with higher education. The analysis of patient satisfaction obtained was greater with low education.

Patients with a level of education $<$ senior high school (junior high school and elementary school) tend to give a good assessment of the quality of service. This is also in accordance with the results of the study by Ibraheem et al. (2013) and Jafari, et al. (2014), which stated that the proportion of subjects who have a higher level of satisfaction are those who do not have education or only have basic education. From this observation it was found that the subjects with low education had low expectations and were thus easily satisfied. Low education makes them easily satisfied with what they get because they don't have anything better that can be compared to what they receive.

From the results of this study, working status has an influence on the assessment of service quality, the influence is negative and statistically significant. Most of the patients who visited the community health centers hadworking status (private employee, entrepreneurs, labors, teachers, and others). From the age characteristics most patients who visit were between the ages of 17-55 years, which is a productive age for someone to work. Job is one of the factors of social structure, so that the existence of this work will influence someone in utilizing existing health services. Job status relates to the assessment of product quality because someone who works gets more information about a product compared to someone who does not work (Ruditya, 2015). 
Journal of Health Policy and Management (2017), 2(1): 81-92

https://doi.org/10.26911/thejhpm.2017.02.01.07

Patients with working status tend to give poor assessment of services received compared to good judgment. This is in accordance with the results of study by Kabatooro et al., (2016) and Ibraheem et al., (2013), which stated that there is an influence of working status with an assessment of service quality. Those who work have more demands that doctors can provide services in accordance with their expectations. Therefore, they have higher expectations compared to those who do not work.

Patients with non-working status (Housewives and students) will tend to give a good assessment of the quality of services received. This is in line with the study of Christasani and Satibi (2016), which stated that in the analysis of the association between job differences and patient satisfaction, it was found that the average student, pensioner, and non-working study subjects tended to be more satisfied with the service received compared to patients with working status, especially civil servants.

Patient income influences the assessment of service quality received; the influence is negative and statistically significant. Most of the income obtained from study subjects is $60 \%<$ regional minimum wage because it is seen from the type of work. Most study subjects consist of entrepreneurs, housewives and labors. Patients with income <regional minimum wage tend to give good assessments of the services provided. This is in accordance with the study of Christasani and Satibi (2016), which stated that the analysis of the difference in income with patient satisfaction shows that the majority of study subjects with small income to medium income are satisfied with the service, thus they give good assessments of service quality. However, some subjects with high income said they were dissatisfied with the services provided and gave a poor assessment.

Patients with income $\geq$ regional minimum wage will tend to give poor assessments of the services provided rather than good judgment. This is in line with the study by Naseer et al. (2012) and Maharlouei et al., (2017) which stated that people from low social class (have low income) apparently tend to be more satisfied with health services compared to higher class people. This shows that socio-economic status is one of the factors that most significantly influencepatients satisfaction with health services. Patients who have low socio-economic status are significantly more satisfied when compared to those who have middle or high socioeconomic status. This is also in line with the study by Jafari et al., (2014), Afzal et al., (2011), and Shah and Baba (2016), which stated that patients with high income will tend to give poor assessments of service quality. With high income, patients have higher expectations for the quality of services received because they are influenced by high public health awareness. Likewise, vice versa, patients with less income will be more likely to give good assessments of the quality of services.

\section{The Influence of Financing Type on Quality Assessment of Health Services}

The results of data analysis statistically show that there is an influence of the financing type on the assessment of the quality of health services. The influence is positive and and statistically close to significant.

The results of the study show that patients with a general financing type (outof-pocket cost) will tend to give poor assessments of service quality. The results of this study are relevant to the study conducted by Maharlouei et al., (2016), which stated that people who have insurance from 
both the government and additional (independent) insurance are significantly more satisfied with the quality of service than those who do not have government insurance or insurance independent. This is also in line with the studyby Fenny et al. (2014) conducted in primary health services. The results showed that the proportion of patients who feel satisfied and insured is higher with the overall quality of health services received compared to those who are not insured.

The results of the study showed that patients with Healthcare Social Securty Agency (BPJS Kesehatan) or with insurance tended to provide very good assessments of service quality rather. This is in accordance with the study byHusnati et al., (2016). From the quality dimension, on the assurance and empathy dimension there were significant differences between ex-ASKES (Health Insurance) and non-ASKES patients, ex-ASKES patients were more satisfied than non-ASKES patients. This is in line with the results of the study by Imelda et al., (2015), which showed that Service Quality consisting of tangible, reliability, responsiveness, assurance and emphaty has a significant influence on patient satisfaction with BPJS. Whereas Non-BPJS patients it is known tangible, responsiveness and emphaty influence the satisfaction of non-BPJS patients.

\section{The influence of accreditation status of health service providers on health service quality}

The results of statistical data analysis showed that there is an influence between the status of accreditation of health services with the quality of services provided to patients. The influence is positive and and statistically significant.

The results of the study showed that community health centers with accredited status tend to provide good quality services to patients. This study is in line with the study conducted by Al-Qahtani et al., (2012), which showed that there are statistically significant differences in patient satisfaction between accredited and nonaccredited hospitals. Patients in accredited hospitals are more satisfied with all services received, except for laboratory services that are rated higher in non-accredited hospitals. Patients in accredited hospitals are more satisfied with the quality of health services provided and show higher satisfaction than in hospitals that are not accredited.

This is also in accordance with the results of Junaidi's study (2009), which stated that the results of statistical tests show that there is a significant association between accreditation status and patient satisfaction. This shows that accreditation is able to improve the quality of health services in community health centeras evidenced by the higher average level of patient satisfaction at an accredited in community health centersthan the level of satisfaction of patients with unaccredited in community health centers.

Accreditation can be used as an effort for health care providers to improve the quality of services provided to patients. According to Alkhenizan and Shaw (2011), there is evidence to show that accreditation programs improve the care process provided by health care providers. There is plenty of evidence to show that accreditation programs improve clinical outcomes of visiting patients. The accreditation program must be supported as a tool to improve the quality of health services.

Based on reliability dimensions, all officers in Sangkrah and Penumping Health Centers already have good skills or expertise according to their main tasks, both registration officers, doctors, nurses, midwives and pharmacy officers. However, 
Journal of Health Policy and Management (2017), 2(1): 81-92

https://doi.org/10.26911/thejhpm.2017.02.01.07

from the dimensions of reliability, patients gave many poor assessments related to waiting time at enrollment and they have to wait in the poly when taking the drug at the pharmacy because most patients said that the have to wait for too long. From the results of observations by the researchers, this is caused by limited energy, especially at the registration site at Penumping Health Center (not yet accredited) because the registration staff was only 2 people. Based on criticism and suggestions from patients, officers are often late or long to enter the card or patient status into the examination room so that the patient's waiting time is longer and does not match the queue. Microphones that often can not work wellcause the patient can not hear so that the examination in poly or taking drugs at the pharmacy does not match the queue.

This is in accordance with the results of study by Anggriani (2016), which stated that the inhibiting factors of service are the lack of supporting facilities and infrastructure at the registration counter (lack of loudspeakers), sometimes slow wifi networks, and large numbers of patients but limited number of officers.

Based on the dimensions of responsiveness, all officers serve kindly and are not indifferent to patients. Whereas in the assurance dimension, all officers, especially doctors, have provided clear information about the patient's diagnosis and the time of examination is in accordance with the specified schedule. However, especially in the Penumping Health Center (not yet accredited), the closing time for patient registration is sometimes not in accordance with the set schedule.

Based on the empathy dimension, almost all patients give good assessments of service quality. Officers are willing to respond to patient complaints and provide opportunities for patients or families to ask questions related to patient disease information or other things, so patients feel cared for by officers. In the tangible dimension, the majority of patients have provided good assessments in terms of facilities at Sangkrah and Penumpinghealth centers in Surakarta. However, there are still a few patients who complain about the limitations of patient waiting rooms both while waiting for queues at registration, poly, and pharmacies. Many patients stand or even wait outside the health centers. The patient also complained that the temperature in the room was hot due to limited fan facilities in the examination room and in the patient's waiting room. Some patients also complain of bad smelling toilets and limited water supply.

Based on the explanation above it can be concluded that there is an influence of accreditation status on the level of assessment of the quality of outpatient services. Heath service facility with an accredited status will provide better quality of service than health service facility that has not been accredited. Thus, the results of this study are in accordance with previous study.

\section{REFERENCES}

Afzal M, Rizvi F, Azad AH, Rajput AM, Khan A, Tariq N (2014). Effect of demographic characteristics on patient's satisfaction with health care facility. J Postgrad Med Inst, 28(2): 154-60.

Afzal M, Khan A, Rizvi F, Hussain A (2011). Patients satisfaction levels in out patient department of a teaching hospital. Journal of Islamabad Medical \& Dental College. 1211(1): 26-29.

Ali FA, Kandou GD, Umboh JML (2015). Analisis Pelaksanaan Rujukan Rawat Jalan Tingkat Pertama Peserta Program Jaminan Kesehatan Nasional 
(JKN) Di Puskesmas Siko Dan Puskesmas Kalumata Kota Ternate Tahun 2014. JIKMU 5 (2): 221-237

Alkhenizan A, Shaw C (2011). Impact of accreditation on the quality of healthcare services: a systematic review of the literature. Ann Saudi Med 31(4): 407-416.

Al-Qahtani MF, Al-Dohailan SK, Al-Sharani HT, Al-Medaires MA, Khuridah EN, Al-Dossary NM (2012). The impact of the status of hospital accreditation on patient satisfaction with the Obstetrics and Gynecology Clinics in the Eastern Province, Saudi Arabia. Journal of Medicine and Medical Sciences 3(10): 665-673.

Ammo MA, Abu-Shaheen AK, Kobrosly S, Al-Tannir MA (2014). Determinants of Patient Satisfaction at Tertiary Care Centers in Lebanon. Open Journal of Nursing 4: 939-946

Andini UF (2014). Hak Perawatan Pegawai Negeri Sipil: Implementasi Pasal 9 Ayat (1) Undang-Undang No. 43 Tahun 1999 Studi Di PT Askes (Persero) Malang Dan Rumah Sakit Umum Saiful Anwar Malang. Jurnal Mahasiswa Fakultas Hukum.

Angella K, Ndoboli F, Namatovu J (2016). Patient satisfaction with medical consultations among adults attending Mulago hospital assessment centre, South African Family Practice. 58(3): 87-93.

Anggriani SW (2016). Kualitas Pelayanan Bagi Peserta BPJS Kesehatan Dan Non BPJS Kesehatan. Jurnal Ilmu Sosial dan Ilmu Politik. 5(2): 79-84.

Azwar A (2009). Pengantar Administrasi Kesehatan, Edisi Ketiga. Jakarta: Bina Rupa Aksara.

Christasani PD, Satibi (2016). Kajian faktor demografi terhadap kepuasan pasien jaminan kesehatan nasional pada fasilitas kesehatan tingkat pertama. Jurnal Farmasi Sains Dan Komunitas. 13 (1): 28-34.

Dewi A, Ramadhan NK (2016). The Difference of Satisfaction Level in BPJS Health Insurance Patient and Non Insurance Patient toward Health Service.International Journal of Public Health Science (IJPHS) 5 (1): 36 - 40

Fenny AP, Enemark U, Asante FA, Hansen KS (2014). Patient Satisfaction with Primary Health Care - A Comparison between the Insured and Non-Insured under the National Health Insurance Policy in Ghana. Global Journal of Health Science. 6(4): 9-21

Ibraheem WA, Ibraheem AB, Bekibele CO (2013). Socio-demographic predictors of patients' satisfaction.Afr J Med Health Sci 12:87-90.

Imelda S, Nahrisah E (2015). Analisis tingkat mutu pelayanan rawat inap dalam upaya peningkatan kepuasan pasien di RSUP Adam Malik Medan (Studi perbandingan antara pasien umum dan pasien BPJS). J. Informatika AMIK-LB 3(3): 92-105.

JafariKelarijani SE, Jamshidi R, Heidarian AR, Khorshidi M (2014). Evaluation of factors influencing patient satisfaction at social security hospitals in Mazandaran province, North of Iran. Caspian J Intern Med 5(4): 232-234.

Junaidi N (2009). Hubungan Status Akreditasi Pusat Kesehatan Masyarakat (Puskesmas) Dengan Tingkat Kepuasan Pasien. Publikasi tesis. Universitas Muhammadiyah Surakarta. http://www.eprints.ums.ac.id. (Retrieved July 20, 2017).

Husnati NY, Setiawati EP, Sunjaya DK (2016). Perbandingan kepuasan pasien eks ASKES dan Non-ASKES di Puskesmas pada Implementasi Ja- 
Journal of Health Policy and Management (2017), 2(1): 81-92

https://doi.org/10.26911/thejhpm.2017.02.01.07

minan Kesehatan Nasional JSK. 1(3): 145-151.

Kotler, Philip, Keller, Lane K (2009). Manajemen Pemasaran, Edisi Ketiga Belas Jilid 1. Jakarta: Erlangga.

Maharlouei N, Akbari M, Akbari M, Lankarani KB (2017). Socioeconomic status and satisfaction with public healthcare system in Iran. IJCBNM 5(1): 2229.

NaseerM, Zahidie A, Shaikh BT (2012). Determinants of patient's satisfaction with health care system in Pakistan: a critical review. Pakistan Journal of Public Health 2(2): 52-61

Profil Kesehatan Kota Surakarta (2014). Profil Kesehatan Kota Surakarta tahun 2014. http://www.depkes.go.id/profil/PROFIL...KOTA_2014/337
2_Jateng_Kota_Surakarta_2014.

(Retrieved February1, 2016).

Profil Kesehatan Kota Surakarta (2015). Profil Kesehatan Kota Surakarta tahun 2015. Surakarta.

Profil Kesehatan Kota Surakarta (2016). Profil Kesehatan Kota Surakarta tahun 2016. Surakarta.

Ruditya AN, Chalidyanto D (2015). Hubungan karakteristik individuterhadap penilaian kualitas produk apotek rawat jalan. Jurnal Administrasi Kesehatan Indonesia. 3(2): 108-117.

Shah AF, Baba IA (2016). Levels of satisfaction of patient treated at Government Dental Hospital with respect to different demographic characteristics. IAIM 3(10): 192-198. 